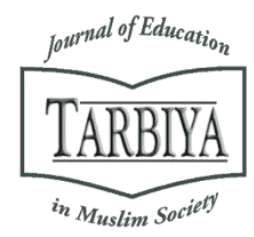

Available online at TARBIYA: Journal of Education in Muslim Society Website:

http://journal.uinjkt.ac.id/index.php/tarbiya

TARBIYA: Journal of Education in Muslim Society, 7(2), 2020, 217-225

\title{
ANALYSIS OF STUDENTS' CREATIVE THINKING ABILITY WITH PROBLEMS SOLVING IN TERMS OF ADVERSITY QUOTIENT
}

\author{
Buchori Muslim*, Siti Suryaningsih, Rizqa Fadhila Aprianti \\ Syarif Hidayatullah State Islamic University of Jakarta, Indonesia \\ E-mail: buchorimuslim@uinjkt.ac.id
}

\begin{abstract}
Received: $14^{\text {th }}$ August 2020; Revised: $24^{\text {th }}$ November 2020; Accepted: $28^{\text {th }}$ December 2020
Abstract

Students' difficulties in chemistry subject are the main cause of their low rate to think creatively. Students with high adversity quotient are most likely to overcome the difficulties in finding a solution to answer the creative thinking problems. The objective of this research is to analyze the creative thinking ability in chemistry from the perspective of adversity quotient. The subjects of the study are 72 senior high school students from XII grade in Tangerang. The sampling applies a random sampling technique. Data collection technique is carried out by giving a test about chemical creative thinking skills in the form is essay question with 0,727 realibility scale. Adversity quotient data is obtained using a questionnaire scale with 0,652 realibility scale. The method used in this study is a descriptive qualitative and quantitative method. The result indicates that camper and quitter subjects are classified as creative and climber subjects are classified as very creative. The different aspects of students' ability in solving problems can be used in mapping students' creative thinking abilities. As a recommendation, to improve creative thinking ability requires a high level of adversity quotient. Therefore, in this research students are expected to explore their creative thinking abilities in the learning process.
\end{abstract}

Keywords: adversity quotient; problems solving; creative thinking ability

\section{Abstrak}

Kesulitan siswa pada mata pelajaran kimia menjadikan rendahnya kemampuan berpikir kreatif. Siswa yang memiliki adversity quotient tinggi maka dapat mengatasi kesulitan untuk menemukan solusi jawaban dari soal berpikir kreatif. Tujuan dari penelitian adalah untuk menganalisis kemampuan berpikir kraetif kimia ditinjau dari adversity quotient. Subjek penelitian adalah siswa kelas XII SMA di Kabupaten Tangerang yang sebanyak 72 orang. Pengambilan sampel menggunakan teknik random sampling. Teknik pengumpulan data dilakukan dengan melaksanakan tes kemampuan berpikir kreatif kimia berupa soal uraian dengan realibilitas sebesar 0,727. Data adversity quotient, diperoleh dengan menggunakan skala angket dengan realibilitas sebesar 0,652. Metode yang digunakan adalah metode deskriptif kualitatif dan kuantitatif. Hasil penelitian menunjukkan bahwa subjek camper dan quitter tergolong kreatif dan Subjek dengan climber tergolong sangat kreatif. Perbedaan aspek kemampuan siswa dalam mengatasi kesulitan dapat digunakan dalam memetakan kemampuan berpikir kreatif siswa. Sebagai rekomendasi, dengan memiliki tingkat adversity quotient yang tinggi dapat meningkatkan kemampuan berpikir kreatifnya. Oleh karena itu, Penelitian ini diharapkan siswa dapat mengeksplorasi kemampuan berpikir kreatifnya dalam proses pembelajaran.

Kata kunci: adversity quotient ;penyelesaian masalah; keterampilan berpikir kreatif

How to Cite: Muslim, B., Suryaningsih, S., Aprianti, R. F. (2020). Analysis of Students' Creative Thinking Ability with Problems Solving in Terms of Adversity Quotient. TARBIYA: Journal of Education in Muslim Society, 7(2), 217-225. doi:10.15408/tjems.v7i2.15234.

Permalink/DOI: http://dx.doi.org/10.15408/tjems.v7i2.15234

"Corresponding author 


\section{Introduction}

Science education aim is to prepare learners in comprehending a concept and improving their high thinking ability (Sa'adah et al., 2020). Chemistry is one of the subjects that is considered difficult for high school students. Chemistry is one of the subjects that is considered difficult for high school students. The difficulty of students in understanding chemistry is marked by their inability to understand concepts correctly and feel depressed (saturated), because chemistry is closely related to other concepts (Lisnawati et al., 2020). Therefore, the chemistry subject has a high level of difficulty (Parker, 2015). Among the higher-order thinking skills that are the essence of the goals of science education are problem solving skills, decision making, critical thinking skills and creative thinking skills (Manik et al., 2020). One of the higher-order thinking skills analyzed in this study is thinking creatively.

The ability to think creatively is one of the competencies that are indispensable in the education of the 21 st century. Creative thinking is a series of cognitive activities carried out by a person towards a specific object, problem, and condition, or an effort towards certain things and problems based on their own abilities (Yazar Soyad1, 2015). Two factors that cause creative thinking hardly develop during learning are a curriculum that is generally designed with broad material targets, so teachers are more focused on completing the designed material but cannot improve their creative thinking abilities (Hasanah \& Surya, 2017a). Meanwhile (Nehe et al., 2017) stated that the development of creative thinking skills is one of the focuses in learning and it is necessary for solving problems.

Munandar $(2012,68)$ explained that the key indicator of creativity or creative thinking can be formulated by fluency, flexibility, and originality. Therefore, the ability to think creatively helps students in solving a problem. Students while facing difficulties in solving problems are influenced by adversity quotient. According (Vinas \& Aquino-Malabanan, 2015) adversity quotient is an intelligence to measure and predict one's ability to respond in facing difficulties. Whereas (Parvathy \& M, 2014) explained that adversity quotient is the human's ability to overcome challenges, problems, and difficulties in their lives. If someone has a high adversity quotient, they will face various difficulties more easily (Zhi-hsien, 2014).

Stoltz (2007) declared that there are three types of people in responding to the problems according to their ability level, namely: (1) Quitter is the type where people prefer to avoid the problems rather than to face it. In this case, someone who chooses to go out avoiding obligations would step back and run away; they stop in the middle of the process of climbing, easily discouraged, and give up. Quitters feel quite satisfied with their basic physiological needs, they are not very active and try to avoid obstacles without continuing to climb. (2) Campers are the type where they attempt to fully possess security needs and a sense of safety. Even though there is an opportunity to climb, they still need to be in a safe position so they will not go far. Feeling bored, they will end their climb and look for a flat and safe place to hide from hostile situations. They choose to spend the rest of their lives sitting and staying there (3) Climbers; in this type, they are struggling for a lifetime. They do not care about any form of difficulty they face although the level of difficulty and intelligence of a person is relatively different. These types of people are the ones who devoted their selves to climbing all his life. Regardless of background, profit or loss, bad luck or good fortune, they continue to climb. A climber is a thinker who always thinks about possibilities, and never allows age bothering them. 
If students have high confidence, they will be able to solve the problems faced in analyzing the questions. One of the subjects that students learn in chemistry is the colloidal system. The colloidal system has contextual and procedural characteristics in which there are concepts: mixtures, tyndal effects, emulsions, coagulation, lyophil and lyophobic colloids as well as water purification that can use materials that exist in students' daily lives or known as environmentally based experimental methods (Muslim \& Erlinawati, 2016). This subject emphasizes the necessary of creative thinking and problem solving skills in order to solve the problems found in the subject (Bybee in Abdul Majid et al., 2015). Thus, to understand colloidal content, students need to improve their ability to think at a high level, one of which is creative thinking (Pusparini et al., 2017). Therefore Individuals like the type of climber are needed in learning chemistry.

Based on the explanation above, this study aims to describe the ability of students to think creatively in chemistry according to their adversity quotient in solving questions on the colloidal subject. This research is expected to provide information on improving students' creative thinking skills in learning chemistry with different range of adversity quotient.

\section{Method}

This research applies a descriptive qualitative and quantitative method. Collecting data technique is conducted using the adversity quotient questionnaire and essay question regarding creative thinking ability. The subjects of this study are 72 senior high school students from XII grade in Tangerang divided into three groups: students in the category of camper, students in the category of quitter and students in the category of climber.
The instrument used in this study is the essay question and the questionnaire of adversity quotient. The test question consists of three colloidal questions that contain three indicators of creative thinking ability according to 2013 curriculum. The first question is about one of the colloidal principles that are adsorption. The second question asks about the use of colloids in everyday life, and the third question is concerned with the function of colloids in everyday life using two colloidal principles namely dispersion and coagulation.

After the data is obtained, it will be analyzed, and then the conclusions are drawn or verified. The result of the data analysis is the determination of the level of creative thinking (CTAL) from the subjects of research with differences in adversity quotient. It is determined from the scores obtained on each problem the students worked on. Each test of creative thinking can describe the indicators of creative thinking, namely fluency, flexibility, novelty. Each indicator in the question contains a mapping score from $0-5$, where subjects who are capable to show the criteria of each indicator in each question will score the maximum of 15 . Subjects with the level of creative thinking ability (CTAL) of 4 (very creative), the total score is $(n)$; $36<n \leq 45$. The level of creative thinking ability (CTAL) of 3 (creative) reaches a total score of (n); $27<n \leq 36$. The level of creative thinking ability (CTAL) of 2 (quite creative) reaches a total score of $(n) ; 18<n \leq 27$, whereas the level of creative thinking ability (CTAL) of 1 (less creative) reaches a total score of $(n) ; 9<n \leq 18$. Lastly, the level of creative thinking ability (CTAL) of 0 (not creative) determined by a total score of $(n) ; 0<n \leq 9$.

\section{Results and Discussion}

Adversity Quotient variable data is gained an avarege score of 61,75 with standard deviation of 
4,278. The variable data of creative thinking ablity gained avarege score of 28,22 with a standard deviation of 7,387 . These findings indicate that the variable of creative thinking ability and adversity quotient have different and various characteristics.

\section{Testing Requirements Analysis}

\section{Normality Test}

The first requirements in analysing data is the normality test, this test is conducted using SPSS 20.0 calculation. Based on SPSS results, is appears that sig adversity quotient value is $(0,124>0,05)$, while the sig value of creative thinking abilities is $(0,174>0,05)$.

Homogenity Test

The second requirements in analysing data is the homogenity test, this test is conducted using SPSS 20.0 calculation. Based on SPSS results, is appears that sig adversity quotient value is $(0,180>0,05)$, while the sig value of creative thinking abilities is $(0,399>0,05)$.

Linearity Test

The third requirements in analysing data is the linearity test, this test is conducted using SPSS 20.0 calculation. Based on SPSS results, is appears that sig adversity quotient value is $(0,330>0,05)$, while the sig value of creative thinking abilities is $(0,11>0,05)$

The following are the analysis of creative thinking abilities resulted from the three groups of a subject in solving colloidal questions based on what has been conducted by referring to the aspect of fluency, flexibility, and originality.
Description of Subject's Creative Thinking Ability of Camper

Camper is capable to show one of the creative thinking indicators in working on the three questions given, which is flexible but they have not shown fluency and novelty. Camper shows the flexibility indicator by giving both answers with problem-solving. For fluency indicator, the subject shows the same way but in the same perspective as well, while in the novelty indicator it has not been fulfilled because the answers given by the subject are still commonly used.

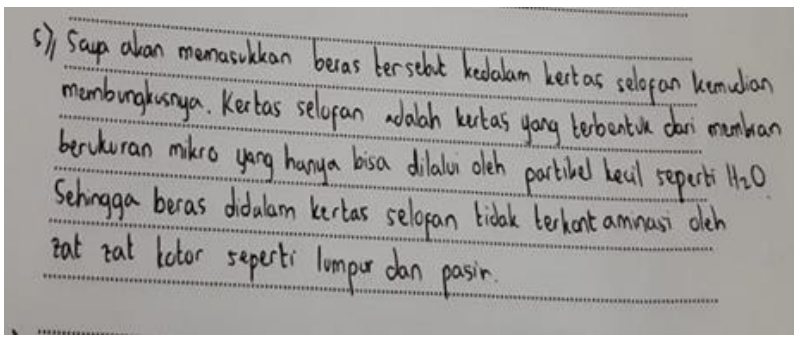

Figure 1.The Results of Camper's Work on Colloidal Question

Based on the students' answers above, it shows that the subject could flexibly express their ideas about the problem in the question and relate them to the concept of the colloidal system. It happened that way because the question's level of difficulty is not too high and it tends to only observe the problem given and then explain in the form of different ideas. Therefore, it is known that detergent is a carboxylic salt which can function as an emulsifier since it has two parts based on its molecular structure, namely a soap tail with non-polar characteristic and a soap head with the polar one. It can dissolve in materials like oil, whereas on the soap head it dissolves in polar solvents such as water (Muslim \& Erlinawati, 2016). From the analysis of these data, the creative thinking ability of the camper can be presented by the table 1 . 
Table 1.Creative Thinking Ability of Camper

\begin{tabular}{|c|c|c|c|c|}
\hline \multirow[b]{2}{*}{ Indicator } & \multirow[b]{2}{*}{ Criteria } & \multicolumn{3}{|c|}{ Question } \\
\hline & & 1 & 2 & 3 \\
\hline Fluency & $\begin{array}{l}\text { Gives different points of } \\
\text { view in the same way }\end{array}$ & $\sqrt{ }$ & $\mathrm{X}$ & $\mathrm{X}$ \\
\hline Flexibility & $\begin{array}{l}\text { Provides various ways of } \\
\text { resolutions, more than } 2 \\
\text { different ways }\end{array}$ & $\sqrt{ }$ & $\sqrt{ }$ & $\sqrt{ }$ \\
\hline Novelty & $\begin{array}{l}\text { Gives an answer } \\
\text { differently from other } \\
\text { subjects, or a unique } \\
\text { answer }\end{array}$ & $\mathrm{X}$ & $\mathrm{X}$ & $\sqrt{ }$ \\
\hline
\end{tabular}

Description of Subject's Creative Thinking Ability of Quitter

Quitter is capable to show fluency indicators of creative thinking ability in working on the three questions given, but they have not shown indicators of flexibility and novelty. Quitters show the indicator of fluency by giving the same way to answer the question but from a different perspective. For fluency indicator, the subject only gives one of two answers in solving problems while the novelty indicator of the subject has not been fulfilled because the answers given by the subject are still commonly used.

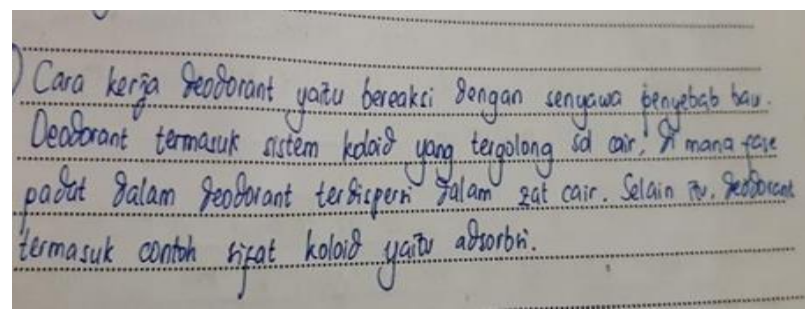

Figure 2. The Results of Quitter's Work on Colloidal Question

The student's answer above indicates that students can fluently express ideas about the problems in the question and link it with the concept of the colloidal system. It can be happened because of the difficulty level of the question is not too high, which only to observe a problem given and then explain it in different ideas. It can be seen from that picture that the colloidal principle adopted in using deodorant is adsorption, wherein the deodorant it contains a compound of aluminum chloride that can absorb sweat. From the analysis of the data, the creative thinking ability of quitter is explained in the table 2 .

Table 2. Creative Thinking Ability of Quitter

\begin{tabular}{llllll}
\hline \multirow{2}{*}{ Indicator } & Criteria & & \multicolumn{3}{l}{ Question } \\
\cline { 2 - 5 } Fluency & $\begin{array}{l}\text { Gives different points } \\
\text { of view in the same way }\end{array}$ & $\sqrt{ }$ & $\sqrt{ }$ & $\sqrt{ }$ \\
Flexibility & $\begin{array}{l}\text { Provides various ways } \\
\text { of resolutions, more } \\
\text { than 2 different ways }\end{array}$ & & & & \\
& $\begin{array}{l}\text { Gives an answer } \\
\text { differently from other }\end{array}$ & & & & \\
subjects, or a unique & $\mathrm{X}$ & $\mathrm{X}$ & $\mathrm{X}$ \\
answer & & & & \\
\hline
\end{tabular}

\section{Description of Subject's Creative Thinking Ability of Climber}

A climber is capable to show two indicators of creative thinking ability in working on the three questions given, which are the indicator of fluency and flexibility, but they have not shown novelty indicators. Climber shows fluency indicators by showing the same way but from a different perspective. For the flexibility indicator, the subject provides two answers in solving problems while the novelty indicator of the subject has not been fulfilled because the answers given by the subject are still commonly used.

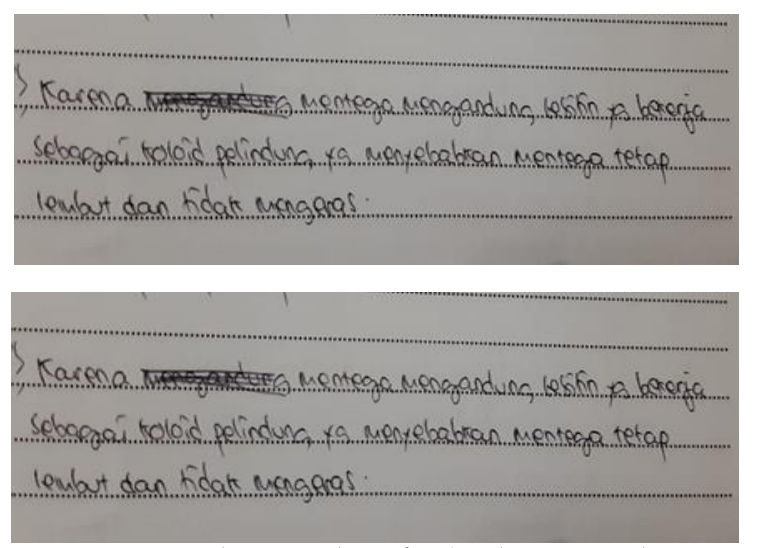

Figure 3. The Results of Climber's Work on Colloidal Question

Based on two students' answers above it shows that students can fluently and flexibly express their ideas about problems in the question and relate them to the concept of 
colloidal systems. It can be happened because of the difficulty level of the question is not too high, which only to observe a problem given and then explain it in different ideas. It can be seen from the picture that the answer above is the answer to question number 2 in the case of creative thinking ability with fluency indicator. Fluency question above conveys that butter does not harden and remains soft when left in the open air because it contains lecithin that functions as a protective colloid. The second picture is the answer to question number 2 in terms of creative thinking ability with flexibility indicator. From the flexibility question above it can be seen that detergent is a carboxylic salt that can function as an emulsifier since it has two parts based on its molecular structure, namely a soap tail with non-polar characteristic and a soap head with the polar one. It can dissolve in materials like oil, whereas on the soap head it dissolves in polar solvents such as water (Muslim $\&$ Erlinawati, 2016). From the analysis of these data, the creative thinking ability of climber can be presented by the table 3 .

Table 3.Creative Thinking Ability of Climber

\begin{tabular}{|c|c|c|c|c|}
\hline \multirow{2}{*}{ Indicator } & \multirow[b]{2}{*}{ Criteria } & \multicolumn{3}{|c|}{ Question } \\
\hline & & 1 & 2 & 3 \\
\hline Fluency & $\begin{array}{l}\text { Gives different points } \\
\text { of view in the same way }\end{array}$ & $\sqrt{ }$ & $\sqrt{ }$ & $\sqrt{ }$ \\
\hline Flexibility & $\begin{array}{l}\text { Provides various ways } \\
\text { of resolutions, more } \\
\text { than } 2 \text { different ways }\end{array}$ & $\sqrt{ }$ & $\sqrt{ }$ & $\sqrt{ }$ \\
\hline Novelty & $\begin{array}{l}\text { Gives an answer } \\
\text { differently from other } \\
\text { subjects, or a unique } \\
\text { answer }\end{array}$ & $\sqrt{ }$ & $\mathrm{X}$ & $\mathrm{X}$ \\
\hline
\end{tabular}

Based on the results of research, it reveals that subjects can fulfill all three aspects of creative thinking ability namely fluency, flexibility, and originality. However, there are only a few students who are capable to achieve the aspect of novelty. They can give various ways of problem solving on each question. The following table are the details of each indicators that are shown by all subjects along with the classification of creative thinking ability level of the subjects.

Table 4. Creative Thinking Indicator

\begin{tabular}{|c|c|c|c|c|c|c|}
\hline \multirow{2}{*}{$\begin{array}{l}\text { Subject } \\
\text { with } \\
\text { adversity } \\
\text { quotient }\end{array}$} & \multirow{2}{*}{$\begin{array}{l}\mathrm{Qu} \\
\text { esti } \\
\text { on }\end{array}$} & \multicolumn{3}{|c|}{ Creative Thinking Indicator } & \multirow{2}{*}{$\begin{array}{l}\text { Scor } \\
\text { e }\end{array}$} & \multirow[b]{2}{*}{$\begin{array}{l}\text { Creative } \\
\text { Thinkin } \\
\text { g Ability } \\
\text { Level } \\
\text { (CTAL) }\end{array}$} \\
\hline & & $\begin{array}{l}\text { Fluenc } \\
y \\
\text { Score }\end{array}$ & $\begin{array}{l}\text { Flexibeli } \\
\text { ty Score }\end{array}$ & $\begin{array}{l}\text { Novelt } \\
y \\
\text { Score }\end{array}$ & & \\
\hline \multirow{4}{*}{ Camper } & 1 & 5 & 5 & 2 & 12 & CTAL 3 \\
\hline & 2 & 3 & 5 & 3 & 11 & (Creativ \\
\hline & 3 & 4 & 5 & 2 & 11 & e) \\
\hline & & $\begin{array}{l}\text { Total } \\
\text { (n) }\end{array}$ & & & 34 & $\begin{array}{l}(n) ; 27< \\
n \leq 36\end{array}$ \\
\hline \multirow{4}{*}{ Quitter } & 1 & 5 & 3 & 2 & 10 & CTAL 3 \\
\hline & 2 & 5 & 3 & 2 & 10 & (Kreatif) \\
\hline & 3 & 5 & 3 & 2 & 10 & \\
\hline & & $\begin{array}{l}\text { Total } \\
\text { (n) }\end{array}$ & & & 30 & $\begin{array}{l}(n) ; 27< \\
n \leq 36\end{array}$ \\
\hline \multirow{4}{*}{ Climber } & 1 & 5 & 5 & 3 & 13 & CTAL 4 \\
\hline & 2 & 5 & 5 & 3 & 13 & (Very \\
\hline & 3 & 5 & 5 & 2 & 12 & Creative \\
\hline & & $\begin{array}{l}\text { Total } \\
\text { (n) }\end{array}$ & & & 38 & $\begin{array}{l}(n) ; 36< \\
n \leq 45\end{array}$ \\
\hline
\end{tabular}

Based on Table 4, it shows that for questions about the colloidal principles adsorption, the question of the function of colloids in everyday life and the question regarding the use of colloids in everyday life using two colloidal principles, namely dispersion and coagulation (Muslim \& Erlinawati, 2016). All subjects are able to show the indicator of fluency from their work by giving a different perspective on the method they use. The flexibility indicator is also shown from the four subjects by how many ways that the subject can work in solving the problem. There are only two that achieve a novelty indicator where the three subjects provide unique answers, new and not commonly used, or give different answers from other subjects.

The results of this study reveal that it is found a similar tendency among the three subjects when working on the problems, which they use a colloidal principle by adopting adsorption techniques. In addition, the three subjects also show a tendency that they substantially know the principle of colloids in everyday life. Furthermore, there are differences in the subjects' creative thinking ability with 
different levels of adversity quotient even with relatively similar chemical capability. This can be seen in the figure 4.

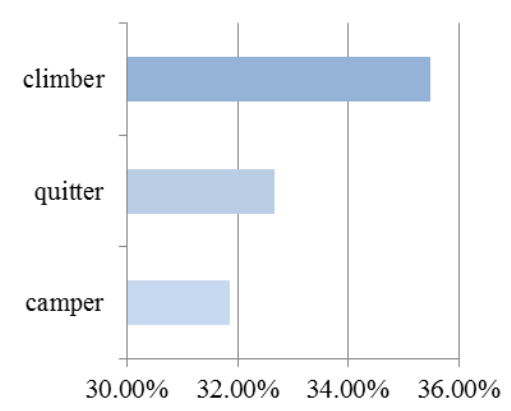

Figure 4. Levels of Adversity Quotient

The graphic conveys that climber is the an aspect that has the highest value compared to the quitter and camper, while the aspect camper has the lowest value. It means that they will always find various alternatives to solve a problem, take difficulties and obstacles as an opportunity to be more advanced and develop, and they will learn more about the difficulties in life. (Hasanah \& Surya, 2017b) stated that climber students always try in solving a problem for getting the best result. It has the same result as the research conducted by (Vinas \& Aquino-Malabanan, 2015) showing that climber subject exhibits the components of flexibility and fluency. Camper's subject shows flexibility and the quitter subject is able to show the fluency component. But the three subjects have not been shown to the novelty component. Therefore, students with climber type will always think of various alternatives to face a problem, take difficulties and obstacles as an opportunity to be more advanced and developed (Stoltz, 2007).

This research also shows that fluency indicator is an indicator that can designate the three aspects (camper, quitter, and climber) in adversity quotient because students can express a lot of ideas smoothly and differently. As for the indicator of flexibility, students can give their ideas in solving problems in many different ways. For the indicator of originality, students can provide original and new ideas, but originality is an indicator with the lowest achievement compared to indicators of fluency and flexibility in this study because students have not been able to put forward original and new ideas about colloidal facts and phenomena in everyday life. This indicates that students are only able to use their creative thinking abilities on indicators of fluency and flexibility.

This indicates that the difficulty of students in generating ideas so they have problems in completing their assignments (Heong et al., 2012). It has the same result as the research that conducted by (Ren \& Wang, 2018) that one's ability to think will affect the success of one's life, cause the ability can be related to what is done in line with the results done. Therefore (Napis, 2018) stated that the ability to measure the difficulty being faced as a challenge as able to maintain it until successfully finding a solution to solve the problem.

In confronting the difficulties, adversity quotient is needed, so that data can change difficulties into opportunities to confront the challenge (Mardika \& Insani, n.d.). Therefore, (Listiawati \& Sebayang, 2019) stated that students with high adversity quotient will be able to face difficulties as responsibilities they have to solve by themselves. Meanwhile, students with low adversity quotient tend to assume the difficulties that arise will continue to come so they will think the obstacles will often appear as well. It means that if students have a good adversity quotient, so they have a higher level of creativity or the students are able to survive and face difficulties, so they are eager for creativity and vice versa. If the adversity quotient of students is low, the creativity will be lower as well.

Stoltz (2007) stated the same that the higher the adversity quotient a person has, the better they are in dealing with the difficulties that they face. Creative students are more likely to ask 
questions that can help them to find answers when solving a problem (Suryapuspitarini \& Dewi, 2018).

This indicates that the role of adversity quotient is important for students because if they want to increase their creative thinking ability optimally, they need to increase their adversity quotient as well. Therefore, to gain a high adversity quotient, students must improve their cognitive abilities in learning to face the problems.

\section{Conclusion}

Based on the analysis and discussion that has been conducted, it can be concluded that the three subjects representing the three aspects of adversity quotient have different characters in showing indicators of creative thinking abilities. Climber subject shows a good score for the flexibility aspect of creative thinking indicators in solving problems and can be classified into level 3 (creative). Quitter subject shows a good score as well for fluency aspects in creative thinking indicators in solving problems and can be classified into level 3 (creative). Whereas, the climber subject shows two indicators of creative thinking ability, namely fluency and flexibility in solving problems and can be classified into level 4 (very creative). However, the three subjects have not shown an indicator of novelty in the ability of creative thinking. This study reveals that there are differences of creative thinking ability in students with aspects of adversity quotient although with relatively similar chemical capabilities.

Based on the description above, students' creative thinking ability has not shown an indicator of novelty, so students need to explore their own abilities when understanding a learning concept. In addition, it is necessary to analyze the factors that enhance and develop adversity quotient and the ability to think creatively.

\section{References}

Abdul Majid, J., Sulaiman, M., Zailani, S., Shaharudin, M. R., Saw, B., Wu, C. L., Brown, D., Sivabalan, P., Huang, P. H., Houston, C., Gooberman-Hill, S., Mathie, R., Kennedy, A., Li, Y., Baiz, P., Pokorná, J., Indonesia, G. B., Objectives, L., To, I., ... Challoumis, C. (2015). No 主観的健康感 を中心とした在宅高齢者における 健康 関連指標に関する共分散構造分析Title.

Acta Universitatis Agriculturae et Silviculturae Mendelianae Brunensis, 16(2), 39-55.

https://doi.org/10.1377/hlthaff.2013.0625

Hasanah, M., \& Surya, E. (2017a). Differences in the Abilities of Creative Thinking and Problem Solving of Students in Mathematics by Using Cooperative Learning and Learning of Problem Solving. International Journal of Sciences: Basic and Applied Research, 34(1), 286-299.

Hasanah, M., \& Surya, E. (2017b). Differences in the Abilities of Creative Thinking and Problem Solving of Students in Mathematics by Using Cooperative Learning and Learning of Problem Solving. International Journal of Sciences: Basic and Applied Research, 1(February), 286-299. https://cutt.ly/0hDE6NN.

Heong, Y. M., Yunos, J. M., Othman, W., Hassan, R., Kiong, T. T., \& Mohamad, M. M. (2012). The Needs Analysis of Learning Higher Order Thinking Skills for Generating Ideas. Procedia - Social and Behavioral Sciences, 59, 197-203. https://doi.org/10.1016/j.sbspro.2012.09.26 5.

Lisnawati, L., Suryaningsih, S., \& Muslim, B. (2020). Penerapan Model Quantum Learning Sebagai Upaya Menurunkan Kejenuhan Belajar Siswa Dalam Mempelajari Kimia. Jambura Journal of Educational Chemistry, 2(1), 18-27. https://doi.org/10.34312/jjec.v2i1.2731.

Listiawati, N., \& Sebayang, S. K. (2019). the Association Between Sociodemographic Factors and Teachers' Guidance Towards Students' Adversity Quotient. International 
Journal of Education, 11(2), 109. https://doi.org/10.17509/ije.v11i2.15341

Manik, A. C., Suryaningsih, S., \& Muslim, B. (2020). Analisis Berpikir Kritis Kimia dalam Menyelesaikan Soal Two-Tier Berdasarkan Level Kemampuan Mahasiswa. Jambura Journal of Educational Chemistry, 2(1), 2839. https://doi.org/10.34312/jjec.v2i1.2999.

Mardika, F., \& Insani, S. U. (n.d.). Adversity Quotient and Students' Problem Solving Skill in Mathematics. 4th ICRIEMS Proceedings, 21-26.

Munandar, Utami. (2012). Mengembangkan Bakat dan Kreativitas Anak Sekolah. Jakarta: PT. Grasindo.

Muslim, B., \& Erlinawati. (2016). Penerapan Metode Eksperimen Berbasis Lingkungan Dalam Meningkatkan Hasil Belajar Kimia Siswa Pada Konsep Sistem Koloid(Ptk Di Kelas Xi Ipa Man 2 Kota Tangerang). Seminar Nasional Pendidikan IPA-Biologi, September, 81-94.

Napis, N. (2018). Analysis Of Physics Problem Solving In The Perspective Of Self Efficacy and Adversity Quotient. Formatif: Jurnal Ilmiah Pendidikan MIPA, 8(1), 31-42. https://doi.org/10.30998/formatif.v8i1.2298

Nehe, M., Surya, E., \& Syahputra, E. (2017). Creative Thinking ability to Solving Equation and Non-equation of Linear Single Variable in VII Grade Junior High School. Ijariie, 3(1), 2146-2152.

Parker, K. A. (2015). I Nterdisciplinary $R$ Esearch and $P$ Roblem $S$ Olving: 5(September 2016), 1-43.

Parvathy, D. U., \& M, P. (2014). Relationship between Adversity Quotient and Academic Problems among Student Teachers. IOSR Journal of Humanities and Social Science, 19(11), 23-26. https://doi.org/10.9790/0837-191172326.

Pusparini, S. tri, Feronika, T., \& Bahriah, E. S. (2017). Jurnal Riset Pendidikan Kimia ARTICLE. Jurnal Riset Pendidikan Kimia, 7(1), $38-51$. https://doi.org/https://doi.org/10.21009/JR PK.072.10
Ren, J., \& Wang, N. (2018). Production-Oriented Approach and Its Implications for the Cultivation of Critical Thinking Skills in College English Instruction in Mainland China. English Language Teaching, 11(5), 33. https://doi.org/10.5539/elt.v11n5p33.

Sa'adah, M., Suryaningsih, S., \& Muslim, B. (2020). Pemanfaatan multimedia interaktif pada materi hidrokarbon untuk menumbuhkan keterampilan berpikir kritis siswa. Jurnal Inovasi Pendidikan IPA, 6(2), 184-194.

https://doi.org/10.21831/jipi.v6i2.29680.

Stoltz, Paul G. (2007) Adversity Quotient, Mengubah Hambatan Menjadi Peluang. Jakarta: PT. Gramedia. Cetakan ketujuh

Suryapuspitarini, B. K., \& Dewi, N. R. (2018). Problem Solving Ability Viewed From The Adversity Quotient on Mathematics Connected Mathematics Project Learning ( Cmp ) With Etnomathematics Nuanced. Unnes Journal of Mathematics Education Research, 7(2), 123-129. https://doi.org/10.1016/j.mseb.2007.09.070

Vinas, D. K. D., \& Aquino-Malabanan, M. G. (2015). Adversity quotient and coping strategies of college students in Lyceum of the Philippines University. Asia Pacific Journal of Education, Arts and Sciences, 2(3), https://doi.org/10.1016/j.funbio.2015.02.00 3.

Yazar Soyad1, B. B. (2015). Creative and Critical Thinking Skills in Problem-based Learning Environments. Journal of Gifted Education and Creativity, 2(2), 71-71. https://doi.org/10.18200/jgedc.2015214253

Zhi-hsien, C. V. (2014). A Study Investigating the Influence of Demographic Variables on Adversity Quotient. 10(June). 